ADDIN, Volume 13, Number 1, February 2019

\title{
Developing the Character of Learning Community at Madrasah Tsanawiyah in Bantul Yogyakarta: Islamic Education in Nusantara Perspective
}

\section{Nurul Kamilati}

Universitas Islam Negeri (UIN) Sunan Kalijaga Yogyakarta, Indonesia

nurul_kamilati@yahoo.com

\section{Sutrisno}

Universitas Islam Negeri (UIN) Sunan Kalijaga Yogyakarta, Indonesia

trisno_63@yahoo.com

\section{Yosaphat Sumardi}

Universitas Islam Negeri (UIN) Sunan Kalijaga Yogyakarta, Indonesia

syosapat@yahoo.com

\section{Abstract}

This research aims to promote the development of the character of learning community at Madrasah Tsanawiyah of Bantul Regency Yogyakarta, and two problems posed to be addressed: why the character of community learning pattern does not realize as it has been expected, and how does the development of the character of learning community at Madrasah Tsanawiyah of Bantul look like? The research uses the Research and Development model that is consisted of four stages: exploration, development, tests, and dissemination. The data were collected by means of observatiosn, interviews, 
questionaire, and review of documentation. The results show: (1) the character of learning community at the Madrasah Tsanawiyah in Bantul Regency has not been fully established because the teachers were not active in preparing their lesson study, and they did not benefit from it. Also, they were too busy in fulfilling their obligations as teachers; (2) the development of the character of learning community at Madrasah Tsanawiyah in Bantul could be implemented through Classroom Action Research-based lesson study plans which are consisted of five stages: consolidation of lesson study concepts, explanation of Classroom Action Research as a form of scientific publication, planning, implementation of action, and reflection.

Keywords: Character, Learning Community, Lesson Study, Classroom Action Research.

\section{Abstrak}

MENGEMBANGKAN KARAKTER KOMUNITAS BELAJAR DI MADRASAH TSANAWIYAH DI BANTUL YOGYAKARTA: PENDIDIKAN ISLAM DALAM PERSPEKTIF NUSANTARA. Penelitian ini bertujuan untuk mengenalkan pengembangan karakter komunitas belajar di Madrasah Tsanawiyah di Kabupaten Bantul Yogyakarta. Ada dua permasalahan yang diangkat, yaitu: mengapa pola karakter komunitas belajar tidak tercapai seperti yang diharapkan, dan bagaimana pengembangan karakter komunitas belajar di Madrasah Tsanawiyah Bantul? Penelitian ini menggunakan model penelitian dan rengembangan yang terdiri atas empat tahap: eksplorasi, pengembangan, tes, dan diseminasi. Data dikumpulkan melalui observasi, wawancara, kuesioner, dan tinjauan dokumentasi. Hasil penelitian menunjukkan: (1) Karakter komunitas belajar di Madrasah Tsanawiyah di Kabupaten Bantul Yogyakarta belum sepenuhnya terbentuk karena guru tidak aktif dalam mempersiapkan pelajaran, dan mereka tidak memperoleh manfaat dari hal tersebut. Mereka juga terlalu sibuk dalam memenuhi kewajibannya sebagai guru; (2) Pengembangan karakter komunitas belajar 
di Madrasah Tsanawiyah di Kabupaten Bantul Yogyakarta dapat diimplementasikan melalui rencana pembelajaran berbasis penelitian tindakan kelas yang terdiri atas lima tahap: penggabungan konsep studi pelajaran, penjelasan penelitian tindakan kelas sebagai bentuk publikasi ilmiah, perencanaan, implementasi tindakan, dan refleksi.

Kata Kunci: Karakter, Komunitas Belajar, Studi Pelajaran, Penelitian Tindakan Kelas.

\section{A. Introduction}

The Article No. 31 of the 1945 Constitution Amendment expressly states "Every citizen has the right to get education". Learning is the right of everyone, and the teacher's obligation is to conduct best teaching performance for their students. Soleh emphasizes as we are now in the global era, society is limited by space and is geographically transformed into a single society. ${ }^{1}$ Furthermore, Winarno states that globalization has been driven by rapid technological developments, while it emerges simultaneously, changes the patterns and attributes of human life in various fields that have implications for high competition. Thus, the life in the globalization era should promote harmonious relationships among individuals to achieve goals in the competitive process and adhere to a global ethic. Quality education services are meant that all citizens have the right to develop the potent abilities. ${ }^{2}$

About this, Amagi states, "The modern education systems developed by nation-states have greatly contributed to shaping not only individuals but also society as a whole. For that very reason, they are apt to be subjected both to public criticism and to undue demands as society evolves." "3 Thus, the education system in the

1 Ilman Soleh, Dampak Globalisasi bagi Kepribadian Kita (Klaten: Cempaka Putih, 2012), 3-4.

2 Budi Winarno, Globalisasi Peluang atan Ancaman bagi Indonesia (Jakarta: Penerbit Erlangga, 2010).

3 Isao Amagi, "Upgrading the Quality of School Education", International Commission on Education for the Twenty-First Century (Paris: UNESCO Publishing, 1996), 44. 
globalization era forms the individual and society as a whole, and a good education system will create a good society.

For attitude and behavior, the Indonesian life is not fully harmonious. Therefore, good quality education is expected to improve the nation's condition such as the intelligent and behavioral aspects. Of this, Sutrisno affirms that one of the globalization's indicators is the higher competition in all aspects of life. This affects Indonesian's educational institutions to produce high competences for graduates. ${ }^{4}$ Zainuddin suggests the competence in thoughts and actions can be generated from educational process. ${ }^{5}$ The surviving institutions should be aware of the needs of the community and need to implement curriculum in context. Bowles and Gintis in Nuryatno agree that educational institutions should play an important role as a productive force to change societal structures through education that is transcended to their social classes. ${ }^{6}$ Education is a strategic way to improve people's statuses. Q.S. al-Mujadalah [58]: 11 states, "Allah exalts the degree of the believer and knowledgeable by degrees." The qualified educational institutions will produce graduates who could improve the self-quality and help their environment improve.

The difference is sunnatullah. Societies may apply Islamic social values such as mutual respect (tasamub), doing good (birr), helping (ta'awun), justice ('ad), compassion (rahmab), caring (ulfab), brotherhood (mu'akhah), or sincerity (musafah). These inclusive and pluralistic Islamic values can be developed through learning in madrasah which is meant to recognize differences and create peaceful environment.

Society is defined as a reflection of the quality of education that takes place within a region through a certain period of time. By

4 Sutrisno, "Mengingat Kembali Jiwa Pendidikan Sebagai Respon terhadap Globalisasi”, Nizar Ali and Sumedi (ed.), Antologi Pendidikan Islam (Yogyakarta: Idea Press, 2010), 131.

5 Zainuddin, Reformasi Pendidikan: Kritik Kurikulum dan Manajemen Berbasis Sekolah (Yogyakarta: Pustaka Pelajar, 2008), 145.

6 M. Agus Nuryatno, "Isu-isu Kritis dalam Pendidikan Islam: Perspektif Pedagogik Kritis", Nizar Ali and Sumedi (ed.), Antologi Pendidikan Islam (Yogyakarta: Idea Press, 2010), 116. 
definition, a qualified madrasah therefore affects the quality of the community. Sato maintained that what is expected from madrasah in the $21^{\text {th }}$ are: first, strengthening both the quality and equality simultaneously; second, the change in the curriculum of the program (goal, achievement, and evaluation) into project/task type curriculum (uphill type in thinking and exploration); third, collaborative learning; fourth, from the teaching expert to be a learning expert to develop collegiality. ${ }^{7}$

In the global era, madrasah should play an important role, in a way that it could become a center of religious education, character education, and science and technology for the interest of Muslims. Therefore, the reformation in the management of madrasah is needed, especially in learning and teaching methods.

There are three pillars that should be maintained at madrasah: students, teachers, and societies. They should be empowered to become a leaning community. Students have collaborative learning when they are studying in class, and teachers have collegial mutual learning in their activities, as well as parents, experts, and governments also need to have contributions in improving the madrasah.

The pillars should be in a harmonic and intercorrelational sector to be learning community. The learning community therefore could be understood as is a collective way for madrasah to jointly work on the achievement of student competence by improving the relationship between students, students with teachers, and madrasah with stakeholders (parents, community, and government).

Reform in the madrasah becomes a necessity in an everchanging society. Sutrisno interpreted the reform in madrasah as a process of providing madrasah to be ready in anticipating the global changing. ${ }^{8}$ For example, Indonesian society as part of the

7 Masaaki Sato, Dialog dan Kolaborasi di Sekolah Menengah Pertama: Praktek Learning Community (Jakarta: JICA, Kementerian Pendidikan dan Kebudayaan, and Kementerian Agama, 2012).

8 Sutrisno, Pembabaruan dan Pengembangan Pendidikan Islam: Membentuk Insan Kamil yang Sukses dan Berkualitas (Yogyakarta: Fadilatama, 2011), 63. 
world community could not avoid globalization today. They should live together in a competitive and peaceful way. Madrasah's students thus are expected to adjust to the global environments, among others, by having competitive competencies equipped with noble character deemed as social capital. Danim also affirmed that the process of education in the global era should be able to mould students into a whole person (physical and spiritual). ${ }^{9}$

For that purpose, the quality learning should be achieved through a prepared learning design that involves society, parents, and goverments. Furthermore, the learning should be meant to enrich the development of students' character by way of puuting effective learning methods so that it will be fruitful.

In this context, the government has the critical role in improving the quality of madrasah through empowering the national curriculum at schools in general via, for instance, adding the content of Islamic religious values, supporting reliable facilities and infrastructure, and providing equal opportunities for alumni of madrasah to pursue their higher levels of education, as wellas giving an opportunity for teachers to be self-indulging in teachers development.

Madrasah Tsanawiyah and its comparable levels in Bantul has now been active in creating the lesson study since 2004 . The teachers of those kinds of schools apply and produce the lesson study as a form of teacher training. They usually form togetherness in formating the lesson study by means of working group, which often raises questions over the achievement of good character in the learning community pattern.

This research was conducted at Madrasah Tsanawiyah in Bantul Regency from June 2013 to October 2017. Based on data of the Ministry of Religious Affairs of Bantul, there are nine stateowned Madrasah Tsanawiyah in this regency and thirteen private, independent Madrasah Tsanawiyah.

9 Sudarwan Danim, Agenda Pembaharuan Sistem Pendidikan (Yogyakarta: Pustaka Pelajar, 2016), 65. 
The approach of this research is qualitative, using Research and Development approach. Based on references of Borg and Gall, ${ }^{10}$ Akker, Plomp, ${ }^{11}$ and Sumarni, ${ }^{12}$ there were four ditermined steps, namely exploration, development, trial, and dissemination.

Sources of data are all components involved in learning including the leadership, teachers, and students. Determination of Madrasah Tsanawiyah as data source was by the use of purposive sampling technique based on the lesson study at madrasah and the lesson study owned by the teacher groups (science, math, and English).

Research data were obtained non experimentally, where data was collected apt to circumstances and there was not human-subjects treatments. Data collection techniques used were observation, interview, questionnaire, and documentation.

The problem formulations of this research are two folds: first, wheather the learning community of teachers at Madrasah Tsanawiyah of Bantul has formed a strong character; and second, how do the teachers achieve the character?

\section{B. Discussion}

\section{The Character Learning Community at Madrasah Tsanawiyah of Bantul}

The character of learning community at Madrasah Tsanawiyah of Bantul Regency is found through exploratory stages during this research and development was taken. The pattern was consisted of collaborative learning, teacher collegial relationships, participation of parents, community, and the local government.

In connection with the learning community, the collaborative learning's pillar is consisted of learning relationship, teachers efforts 1983).

10 W.R. Borg and M.D. Gall, Educational Research: an Introduction (London: Longman,

11 T.Ny. Plomp, Educational and Training System Design (Enschede, The Netherlands: University of Twente, n.y.)

12 Sri Sumarni, "Pengembangan Model Pendidikan Karakter Berbasis Penguatan Modal Sosial bagi Mahasiswa UIN Sunan Kalijaga", Disertasi, Program Studi Ilmu Pendidikan Pascasarjana Universitas Negeri Yogyakarta, 2014. 
to increase learning relationship, learning with the jump, and the achievement of goal. The collegial relationship of teacher's pillar is consisted of discussion of teaching practice, observing each other, creating ideas together, and encouraging each other. The participation of parents, community, and government pillar is consisted of parent participation, community involvement, and the government sharing in learning as well as the activities of madrasah.

\section{Collaborative Learning}

Student relationships in the classroom should be a mutual learning. Higher achieving students would assist those with less achieving. Furthermore, the researcher asks to higher achieving students, such as "Do you feel that any friends who do not understand the task given by the teacher?" The following Figure 1 is their responses.

Data collection was conducted on forty-two higher achieving students from ten classes. Twenty-four students who felt the lack of understanding of the subject matter were understood, eight students are unaware, and ten students are hesitant about their existence. The above numbers are depicted in the percentage chart as follows:

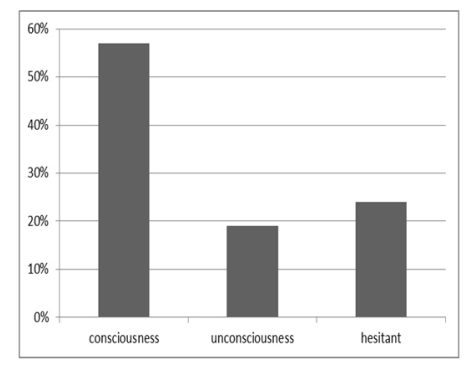

Figure 1

Distribution of Highly Responsible Students' Response in terms of the Consciousness of Less-Mighty Companions

According to Figure 1, higher achieving students who are aware of lowachieving students are higher than those who are unaware and hesitant. It has not been showed a high category. The class should 
develop equality and socially caring attitudes where each student is aware of and sensitive to friends who need assistance.

There are no mutual learning relationships which are expected to occur because low-ability students do not demonstrate an attempt to ask questions and or ask for help from capable friends. The reluctance of asking help is related to low achieving students. One hundred and twenty-one of one hundred and sixty lower achieving students are reluctant to ask for help because they do not know what to ask $(76 \%)$, twenty students are reluctant to ask for help despite knowing the question (12,5\%), and nineteen students dare to ask for help $(11,88 \%)$. This is illustrated in the following Figure 2.

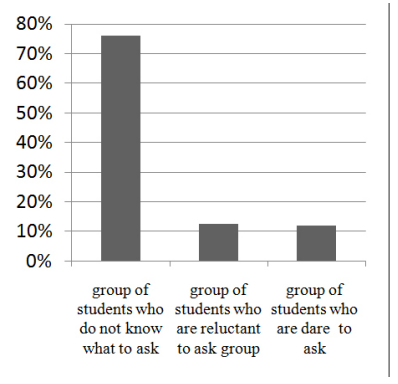

Figure 2

Distribution of Willingness of Lower Achievement Students to High Achievement Students

Furthermore, the researchers asked higher achieving students who are aware of a poor understanding friend, "What kind of helps do you give to a friend who has learning difficulties or lack of understanding today?"

Twenty students out of twenty-four students give help for him or her. The researchers noticed further that they provide assistance because they are encouraged by teachers to work in group and shared media. The unware and hesitant group provides assistance also to their friends because of learning which was imposed by the 
teacher requiring them to work together and involve friends.

Secondly, teachers improve the mutual learning relationship. Interview with students about the benefits of group activities where over $80 \%$ of students states helpful, $14 \%$ of students states useless, and the remain $(6 \%)$ states not knowing as depicted in Figure 3:

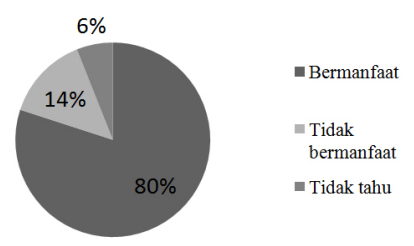

Figure 3

The Benefit of Group Activity

Teachers use media to improve students mutual-relationship. Here are fifty students' (higher, medium, and lower) responses to the media's benefits. Thirty- seven students state that the media is more clarer to be used the teachers in delivering lesson. Only thirteen students state "no" to the question. The reason behind this is that they do not understand how to use media, media size is too small, and the amount of media equipments are not sufficient. The answers provided by the students serve as a reflection for the improvement of future learning and lesson study or teacher reflection for the implementation of non lesson study.

Other students' responses about media are as all students express the spirit of learning better than without using media. They are very interested in objects brought by teachers either from the laboratories or provided by the teachers or requested by each group. The students feel more successful in learning when using media. Accordingly, this is because learning becomes easier, having a long-lasting understanding, and they can ask friends for interactive 
learning. All students say the use of media is fun. They compare it also with learning without media where they feel bored, if only asked to read the book and solve the problem. They stated that if learning is observed by other teachers (lesson study) then it is certainly exciting for them. One student comments:

"Why? When there are guest teachers (observers) present, it certainly make the learning interesting because the teachers carry media and share with us as we work in group."

Students claim that the relationship between students in the class becomes closer. They use the media together to complete the task required by the teacher where someone holds, operates, and treats the media according to the teacher's instruction. Thus, the learning using media is meant to improve students' collaboration by encouraging the achievement of learning objectives in a fun way. This media as a means of collaborative learning among students. The benefit of media for teachers is to help them learn the process so that learning objectives are more easily achieved.

The next teachers' effors to improve collaboration learning is by inviting students to think. This invitation is not a sentence "let's think", but rather an activity encouraging students to break something or a challenging question related to the activity.

The researchers look at the teacher who delivers a question which later is answered by a student or by the class without any clarification. Afterward, the teacher state "true" but without further discussion. However, not all teachers always do this as many teachers also explore the questions and answers so that it becomes a set of collaborative tools. Interview of model teachers on this matter is if all the questions asked are used as a collaborative tool will take a lot of time because the students involve also do not answer much and the experience of carrying out several times congestion.

The teachers' effort in improving the collaborative learning is by encouraging active students. Based on observation, group activities carried out first rather than individual activities. Interviews 
with teachers proving that "group activities is first, then individual activities". Next, the researchers ask whether the content/material of the individual activity should be the same as the group activity? The answer is "yes." The answer of the model teacher above is precise. In collaborative learning and group activities are a means of classroom learning in achieving individual competence. Students learn to solve difficult problems in groups. It is therefore expected that if they successfully complete in groups, they will be able individually.

\section{Teacher Collegial Relationships}

The collegial relationship of teachers are four folds: (a) talking about teaching practice; (b) observing each other; (c) sharing common ideas; (d) encouraging each other.

The teacher collegial relationship during the lesson study has shown a relationship that satisfies these four aspects. The whole stage of lesson study activities is done actively, mutually cooperation, and mutually beneficial. They work together in developing the lesson plans, observing the class together, and reflecting.

The following is the results and discussion when the teachers do their work outside the lesson study.

Talking about teaching practice is quite good. Based on questionnaire given to fifty teachers, thirty-eight $(76 \%)$ of the teachers are used to discuss the learning activities with fellow teachers; forty teachers $(80 \%)$ talk to each other about improving the quality of madrasah with fellow teachers. This means that teachers talk to each other teachers about their progress. However, there are also teachers who talk outside of their duties.

Teachers discuss matters in one group subjects on topics they have worked on related to certain materials that have also related to the material that will be taught. For example, on science a teacher asks a fellow math teacher: "Have you been taught about graphics?" The science teacher asks this question because in science there 
are materials to observe of Ilmu Pengetahuan Alam (IPA, Natural Science) objects whose results can be processed into graphs and then are analyzed. Moreover, teachers who teach the same subjects in different classes sometimes ask each other on the materials achievement and the learners' learning outcomes for a particular subject. The researchers once asked a math teacher in parallel class VIII ranging from $\mathrm{A}$ to $\mathrm{C}$ to ask the math teacher who also teaches in the parallel $\mathrm{D}$ and $\mathrm{E}$ about learning in class.

The teachers who teach the same subjects albeit different levels of the ability the students possess also discuss the strategy to manage their students. Teachers who teach in highly skilled classes sometimes complain about some students who can not learn quickly. The following are their sugestions.

$$
\text { "Teach, slowly." }
$$

"The children in the class are divided into groups and given the questions to get done together."

"The lesser students are given extra training and assignment."

"Set up study groups."

"Pair less students with smart ones."

"Ask good students to help the less students."

The above options offered are discussed together to choose one or more of the possible options. Then, the teachers implement them.

Related to the above issue, some madrasahs have arranged the teachers in one lesson group to sit one close to the other, and based on the interviews with the teachers, proving that they often discuss various material difficulties and strategies delivered to the students, especially before the national exam days, where all teachers are involved to prepare teaching materials in turn. Every teacher should know the limit of the material that has been completed by the previous teacher and the absorption of the students toward material. 
Furthermore, the teachers are asked about their discussion on teaching practice before learning with other fellow teachers, especially at the same or at one group subjects. Information is obtained from fifty teachers. The results are thirty five teachers $(70 \%)$ conducting discussion, and the rest does not discuss the teaching preparation teaching with their fellow teachers. Then these thirty-five teachers are asked continously through interviews but only twenty-four available in discussing the lesson in the group; six teachers discuss with fellow subject teachers at their madrasah, and five others discuss with teacehrs of different subjects.

The topic of discussion is on teacher-relative to administration, problem solving, current materials, current application of learning methods, the use of practice tools, selection of media suitable to environment, and assessment.

Based on the results of interviews, the teachers are accustomed to talking about learning, madrasah, and the preparation of teaching among them within the scope of working on lesson study group and madrasah. There has been a good commitment of the teachers toward the success of students. In these activities the character of teachers are developed through discussing teaching practices, such as curiosity, communication, creativity, and hard working.

The level of talking about teachers' teaching practices, however, can actually be improved not only with the teachers' friends in one subject but they can freely communicate with theachers of other subjects. The principle is that they talk about the practice of learning which is not only limited by the scope of matter.

The topics are discussed by teachers can be practically reviewed in the existing teacher forums related to the lesson study. The main constraint of the continuous lesson study is that many teachers are busy with routine activities.

So one of the solutions is that to create videos of the lesson study, which are are observed by other teachers who do not follow the lesson study and when they do not teach. The videos begin with 
planning, practicing, and stageseeing. The advantage of using the videos is that teachers' observations can be repeatedly conducted. The weakness, however, could ascend from the instructional videos created by the teachers which probably have no focuses on the students with learning difficulties. Learning the videos that have been made still put teachers as the model and the central subjects. The teacher who gets the task of making the video should be equipped with skills and techniques of creating quality learning videos.

The teachers further can observe one another. Data outside the lesson study is obtained from fifty teachers focusing on: (a) observing the learning of fellow teachers; (b) observing the learning by fellow teachers; (c) obtaining observation class results; (d) observing fellow teachers; (e) considering the improvement of learning for themselves; (f) considering the improvement of learning by fellow teachers; (g) providing the appearance of best teaching techniques during the observation; (h) providing the best media applied to the appearance during the observation; (i) providing the best performance appraisal when observing; (j) providing the best teaching performance during the observation based on knowledge and skills possessed.

The most teachers' responses about the ten aspects are "no", meaning the observation on other teachers by the teachers level is lower. The number of responses opf the "yes" answer is three coovering all aspects except the first aspect (observing learning of fellow teachers).

All teachers who are being observed get benefits from the observation activities because they use the observations to improve their performance, which is also supported by seriousness of the teachers who are observed as performing best actions by using best methods, media, and assessment.

Creating joint-ideas are further used by the teachers to build lesson plans whether are delivered to the official forums or not. Based on the questionnaire given to the teachers on creating shared idea, 
anonymous teachers stated that the meeting forum is essential for conveying ideas, and via this forum feedbacks delivered sometimes are incompatible with the topics. In the meeting forum, the topic that might be about learning, facilities, infrastructure, or finance. However, the teacher's meeting is still talking about madrasah and its problems but least on learning problems.

There is a forum that focuses on the problem related to learning called lesson study. Some madrasahs joined for the formating the teacher working forum-based lesson study. The implementation of the lesson study in the madrasah where the research took place shows that the participants are active members of the forum that has conducted the lesson study. They are science and math teachers working in the forum. All teachers can share their ideas and agree on the ideas through the lesson study forum. The teachers share ideas in order to be better learners when they plan their teaching. The teacher participants work together in making the lesson plans, attachments, and the observation tools. They devote all their minds and think of the best ways of teaching.

Ideally, teachers who follow the forum based on the lesson study should implement it based on their experience in class. While other teachers do the lesson study with them. Unfortunately, not all madrasahs have developed such lesson study. The lesson study can be constructed to further improve teacher's participation.

Next, encouraging each other is kind of teachers partnership to produce best learning experience by providing practical examples related to methods, media, or the assessment of learning, as well as encouraging motivation.

The fifty teachers who were given questionnaires about giving good examples of teaching. The examples can be through learning documents and application of methods, media, and the assessment, etc. Not all teachers are willing to give complete explanations when they are asked by the researchers. The following are some of what they say: 
"If they do not ask, it means they understand."

"I have explained before, including giving the title of his book."

"I feel bad explaining without being asked."

However, there are teachers who are willing to explain in detail without being asked by the teacher explicitly. They know the teachers need help from the conversation with other teachers. Tracing further, some of these willing teachers explain in detail are those who have become accustomed to being active in the lesson study. They have higher self-confidence to explain because they have sufficient mastery on the practice of learning. The teacher attempts to encourage less teachers to have the necessary skills for a good lesson.

Character attitudes developed are tolerance, hard working, curiosity, and loving to read. Highly skilled teachers are willing to provide an explanation of learning to teachers who have not understood the lessons well.

\section{Participation of Parents, Community, and Government at Madrasah Tsanawiyah}

During ten sessions of observation on the lesson study, only once the researchers notice the presence of one parent. Affirmation from the teacher stating that the parent is active in welcoming the madrasah's invitation. Although he does not make a comment when the reflection of learning, researchers have shown the concern of parents and as a good form of madrasah relationship with the parent. Unfortunately, his presence does not continue although the madrasah still invites him in the next lesson study.

Other madrasahs, particularly, have never invited the parents/ guardian of the students to attend a series of lesson study activities. Therefore, they are not being aware of the activities that can actually be used as media to share imformation and create common 
understanding of how to achieve successful education for their children.

The madrasah committee as an independent institution consists of parents/guardian of the students and community leaders. It is also concerned about the education of madrasah that rarely invites the observing teachers to learn in the lesson study activities. The ideal of the madrasah committee should be consisted of the community leaders, the parents/guardians who are economically sefl-sufficient, the parents/guardians who are economically poor, educational experts, and the potential donors. Based on the interviews, it is found that the composition of the madrasah committee does not exist only the combination between educational experts and potential donors.

When the researcher asks to the managers about the lesson study, their answers are unimously the same:

"So far, parents and guardians have never been invited in the lesson study activities. The parents are invited when there are religious teaching activities on Wage Sundays, Thursdays night, etc. At the same time, madrasah conveys information about the madrasah, administration, the learning outcomes, and other announcements."

The researcher further asks the headmaster of the madrasah, "What if the parents/guardians of the students are being involved in the lesson study activities?" "Is it possible?" The head of the madrasah replies:

"It is possible, especially the parents and guardians are at the same time being learners to know what has been done by the teachers. If they have seen how the the teachers have worked hard to have their children successful, then it will certainly increase participation of the parents. At least the parents can encourage their children to be more diligent enough in their learning. In addition, the parents/guardians become more understanding that educating is very difficult. Currently, if there is a failure of learners, the parents/guardians tend to blame the madrasah."

The parents/guardians of students are actually very happy if they can be present in the learning activities, but this is not common in Indonesia. 
"If I am allowed to watch my children studing at madrasah, I feel happy. I will see their teachers who have done excellent jobs and worked hard although my son has not achieved the expected results. Of course, we together will find the solution. So far I have left my son in the madrasah to be educated to become clever and well behaved child."

Accordingly, the absence of the parents/guardians on the lesson study activities because they do not know the essence of the activities. If they are invited and know exactly what to do then many parents/guardians would like to come.

The community participation in the non-lesson study activities was also not found during this research. The community members of various professions who attend the learning activities could provide reinforcement to the practice of concepts in everyday life. The community members are journalists, businessmen, doctors, police officers, and other professions. The present community can motivate the learners as well as take the opportunity to provide ideas related to the expected learning process or completeness of the application of the concept in accordance with many opinions.

The government participation in the lesson study activities is quite good. They come to some lesson study activities especially at the "do stage" and "see stage". The government is officials of the Ministry of Religious Affairs of Bantul and the madrasah supervisors, trying to get information of the lesson study activity.

Their presence provides valuable motivation for the madrasah in implementing the lesson study. In some madrasahs, the teachers are open to the classroom activities as well as supervising teachers by supervisors and the headmaster of madrasah. The teachers are more eager to carry out the lesson study in addition to implement the madrasah programs as mandatory. Based on reflections, the supervisors give the operational advice to the teachers to improve the learning activities, complementary media, or assessment apt to the findings at the "do stage". 
This well-run activity in some madrasahs is quited because the madrasah put the priority activities from the Ministry of Religious Affairs that demand immediate management and settlement. When the researchers ask the madrasah supervisor about the implementation of the lesson study which temporarily discontinues in a madrasah, he replies that because the madrasah guarantees the activities of the Ministry of Religious Affairs of Special Area of Yogyakarta. The supervisor feels there are the benefits of the lesson study that could improve the teachers' competence and facilitae their work academically, but he is powerless when there are other activities requiring immediate resolution.

The character of learning community at Madrasah Tsanawiyah of Bantul Regency has shown an increasing need of contribution from the lesson study. The lesson study as a system of activities is deemed to realize the learning community which also requires the transformation of more interesting activities for the teachers as well as the parents/guardians.

Attitudes developed are religious values, discipline, democracy, spirituality, togetherness, communication, peaceful love, and responsibility. Based on the findings, the community learning characterized at Madrasah Tsanawiyah of Bantul Regency is as follows: First, the three pillars of learning community exist: collaborative learning, teacher collegial relationships, and participation of parents and the community, but the government of Bantul Regency has not been synergic in realizing the learning community. Second, the character of the community learning which is characterized at Madrasah Tsanawiyah in Bantul Regency has shown an effective collaborative learning. Third, the community learning which is characterized at Madrasah Tsanawiyah of Bantul Regency has shown the collegial relationship. Fourth, the pattern of community learning is characterized at Madrasah Tsanawiyah of Bantul Regency has shown the participation of the parents, community, and the government of less category. Fifth, the pattern 
of the learning community character can not be shown to be realized well at Madrasah Tsanawiyah of Bantul Regency. Sixth, the lesson study as a system of activities is to realize the learning community requiring the transformation of more interesting activities for the teachers and the parents/guardians of students.

Based on the characteristisc above, it is found that the lesson study needs to be developed into a more interesting teacher activity for the learning community components: collaborative learning, teacher collegial relationships, and the participation of parents, community, and the government to become better and together successfully realize the character learning community.

\section{Developing the Characteristics of the Learning Community}

Based on the research findings at the exploration stage, it is necessary to develop a learning community characterized through lesson study activities that are more interesting for teachers and packaged according to the needs of teachers. The model development stage has three activities such as literature review, forum group discussion, and expert validation.

Based on the "Tri of Education Center" of Ki Hadjar Dewantara, schools with families and communities play a synergistic role to realize children who are ready to take part in the community. Thus, it is necessary to design a cooperation of three environments that facilitate the establishment of a harmonious relationship. Furthermore, character Education Theory Thomas Lickona explains that the most important thing of character is the practice of character in everyday life for children and adults. It needs a design that is designed as a vehicle for development and character implementation. In line with the above, Urie Bronfenbrenner in developmental ecology theory states that the environment affects the development of children. School is expected to provide a conducive place for the development of children to optimal. 
The demand for teachers is having a good performance through the achievement of teacher competence: pedagogic competence, personality competence, social competence, and professional competence. These four competencies are achieved through a series of programmed, integrated and systematic activities in the form of sustainable professional development.

The sustainable professional development element of the scientific publication deposits a critical contribution for the realization of good teacher performance. Teachers prepare scientific papers and publish them in various forms. One form of scientific papers that provides substantial benefits for improving learning and simultaneously improving teacher competence is classroom action research.

The classroom action research has four stages, namely planning, action, observation, and reflection. Lesson study as a teachers forum that has three stages such as plan, do, and see. Lesson study is not a research activity, but can be designed as a research. Based on the results of exploration stage, the character learning community at Madrasah Tsanawiyah Bantul Regency has been formed with the support of the pillars of collaborative learning; teacher collegial relationships; and the participation of parents, communities, and governments. The three pillars can be established in lesson study activities. However, the implementation of the lesson study required immediate settlement, other time-consuming activities, and the low motivation of teachers to implement lesson study.

The first FGD was followed by the heads of madrasas in Bantul Regency when they followed teacher training. They have long known lesson study when as teachers and as head of madrasa. Lesson study introduced in Bantul since 2004.

The following is a description of the implementation of the training in which the FGD is conducted as well. FGD was held on July 2, 2015. The purpose of FGD was to obtain information about the implementation of lesson study which was more exciting 
for teachers in order to increase the competence and fulfillment of teacher's job demands.

Benefits of the FGD was the information obtained used as materials to prepare steps lesson study activities combined with CAR. FGD results were: (a) in lesson study activities at the same time can be implemented CAR; (b) the implementation steps were incorporate the CAR stages in the appropriate lesson study stages.

The forum had suggestion that implementation classroom action research in lesson study can run well and be suitable with the principle of collaborative lesson study so making of classroom action research in group.

Furthermore, the second FGD was at Ganesha Education University in Singaraja on September 18, 2015. The forum attended by the researcher in lesson study at the concurrent session of International Conference on Lesson Study $6^{\text {th }}$ entitled "Lesson Study Contribution to Curriculum Implementation at Classroom Level".

The researchers presented paper entitled "Classroom Action Research based on Lesson Study at Islamic State Junior High School in Pundong Bantul". The purpose of FGD was to develop a lesson study whose data can be used for classroom action research. The benefit of FGD was to contribute to the development of lesson study which was more interesting for teachers by using lesson study data as classroom action research data.

The problem formulation were: (a) how was the lesson study obervation format can be used for classroom action research? (b) how to use lesson study data for classroom action research? FGD conclussion as following: (a) lesson study format can use the format of classroom action research instruments; (b) lesson study data was analyzed and used to answer classroom action research.

Based on the FGD results, a development model is enhanced in the form of conceptual model and procedural model. 
Conceptual model design developed based on classroom action research and lesson study concepts. Based on the character learning community pattern that has been compiled during the exploration phase, it is done that the lesson study as the system of the activity of realizing the learning community character has not shown satisfactory success. Lesson study is not an integrated system of activities that can integrate the three pillars of learning community.

Some teachers are reluctant to implement lesson study for various reasons. The reason that often comes up is lack of time and do not feel benefit directly. On the other hand, based on Regulation of the Minister of State Apparatus Empowerment and Bureaucratic Reform Number 16 Year 2009 about Teacher Functional Position and Credit Score, teachers are required to fulfill credit numbers according to their rank and position through sustainable professional development activities. Classroom action research is one of teacher proffessional development that contributes greatly to the improvement of student competence and the ability of teaching teachers.

Furthermore, there is a cycle in classroom action research. The cycle is a distinguishing feature of other types of research. Therefore, the cycle must be implemented correctly. The classroom action research cycle consists of planning, observation, action, and reflection. Lesson study also is a cycle that has three steps that implemented and repeated.

Then prosedural model design proposed the following. Firstly, participants get consolidated concept and principle of lesson study. Secondly, participants obtain classroom action research material as one form of scientific publication for teachers. Thirdly, participants are guided to be able to identify the learning problems experienced by students in the classroom according to the subject. Fourthly, participants are guided to establish actions taken in order to solve the problem. Fifth, participants are given an explanation of student 
observation instruments and teacher performance instruments in applying the determined actions.

The expert are widyaiswara of the Ministry of Religious Affairs. They were one widyaiswara who become The Team of Appraisal of Credit Score of Scientific Publications of Teachers; two widyaiswara who specialized in classroom action research; and two widyaiswara who hasspecialization of lesson study.

The event was in Jakarta at the Center for Education and Training of Technical Education and Religious on June 4, 2016. The composition of the event of expert validation activities as follows:

Researchers convey the purpose of execution of expert validation to expert forum discussion participants, namely: looking at the Lesson Study Guidelines Classroom Action Research.

Lesson Study Guidelines Class-Based Research, tested to Madrasah Tsanawiyah teachers in Bantul Regency. The following recaps the results of teacher responses to the Lesson Study Guidelines Classroom Action Research. Participants stated strongly agree (SS) against fifteen statements. The statements numbres are 3, $4,5,6,7,11,14,15,16,17,18,20,21,22$, and 23 of twenty three statements. The percentage of the Guidance statement that received a strongly agreed response from the participants was $65,21 \%$. The remaining $34,79 \%$ is the agreed response of the participants.

After development stage, the validated development model was piloted at State Madrasah Tsanawiyah (MTsN) Gondowulung, Bantul Regency that is testing stage. This trial is to apply a better pattern of community learning based on the pattern development outcomes that is classroom action research based on lesson study. After the trial, a revision is made based on the findings of data and input.

The test stage was on October 29-31 until mid November 2016 followed by 37 MTsN Gondowulung teachers as participants. Activities undertaken in accordance with the activities stages contained in the classroom action research based on Lesson Study 
Guide are as follows: (a) consolidation of of the lesson study concepts; (b) Classroom Action Research as a form of scientific publication; (c) problem identification; (d) identification of action; (e) formulation of the title; ( $f$ ) preparation of Classroom Action Research proposals; (g) Classroom Action Research based on lesson study planning (CAR planning); (h) implementation of action; (i) reflection.

The development of character learning community as well as lesson study based on classroom action research illustrated in Figure 4:

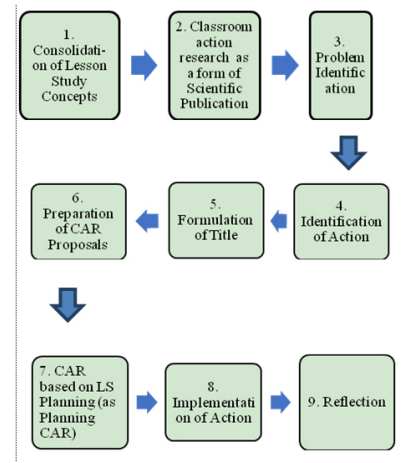

Figure 4

The Flow Chart of Lesson Study Based Classroom Action Research Pattern

The pattern of lesson study based on classroom action research which have been tested then got input of improvement by expert of lesson study and classroom action research. The number of steps is simplified into five steps below. In step three includes several activities as well as problem identification, action identification, formulation of classroom action research title, preparation of classroom action research proposal, and planning of classroom action research.

The steps are following: (a) consolidation of the lesson study concept; (b) submission of CAR as a form of scientific publication; (c) planning; (d) implementation of action; (e) reflection. 


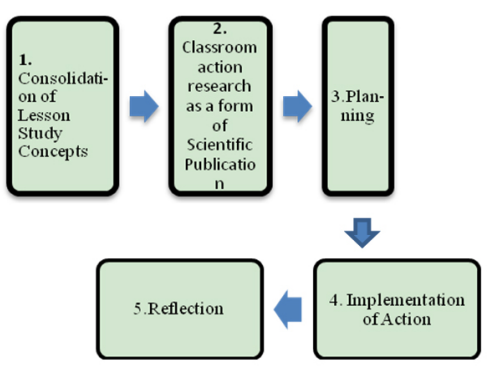

Figure 5

The Flow Chart of Lesson Study Based Classroom Action Research Revised Pattern

Technical mechanism of development patterns proposed as follow: (a) the implementation of the lesson study fulfills the implementation stage of the plan-do-see; (b) all lesson study participants are encouraged to conduct classroom action research in accordance with their respective classroom issues; (c) learning planning activities start from identification problem and identification action; (d) based on the identification of the problem made an instrument of observation of the learners; (e) based on the identification of the action made the teacher performance observation instrument; ( $f$ ) taking turns lesson study for each model teacher; $(\mathrm{g})$ model teachers and up to three observers are CAR teams (researchers and collaborators), other observers help complete the stage of action data; (h) stage of action as well as stage do by participants of lesson study; (i) every observer of lesson study provides reflection on the observation of learning; ( $j$ ) observation results are used to improve learning in the next cycle.

The activities undertaken at the dissemination stage are publication, socialization, and acceptance of the product. Publications that have been done to the user through the publication on the web of Regional Office of the Ministry of Religious Affairs of Yogyakarta. Information in the form of lesson study activities 
that appeal to teachers who provide direct benefits on improving the competence of students and teachers. Also in this activity as well as teachers can carry out classroom action research activities.

Product socialization in the form of lesson study based on classroom action research is done through the training activities of the researcher as a resource and interview to the related parties.

Here are the socialization activities that researcher has done in some training locations. (a) The Teacher Quality Improvement Workshop on November 25, 2017 at MAN 1 Gunungkidul; (b) The Training of Additional Assignment of Headmaster of Madrasah Ibtidaiyah of the Ministry of Religious Affairs of Pati Regency on December 24-26, 2017 at Hotel Pati; (c) The Piloting Training of The Continous Professional Development Madrasah Ibtidaiyah Teachers of Kebumen Regency on January 25, 2018 at the Office of the Ministry of Religious Affairs of Kebumen Regency; (d) The Substantive Technical Cooperation Training of Preparation of Learning Plan for Madrasah Tsanawiyah Teachers in Pemalang Regency on February 14-18, 2018 at MTsN 1 Pemalang; (e) The Substantive Technical Training of Teacher Performance Assesssment and Continous Professional Development for Supervisor of Bantul Regency on April 25, 2018 at The Office of Ministry of Religious of Bantul Regency.

Parties related to the use of the product are requested to respond to the sustainability of the product implementation; appropriateness of product implementation with lesson study concept and the CAR concept; and product clarity as a guide. They are teachers, heads of madrasas, government, widyaiswara, and officials of the institution of sincerity.

To make it easier for them to understand the product given the opportunity to read the script of the product and afterwards give response through the prepared questionnaire instrument, after which they give acceptance of the product. They are teachers who active in lesson study, headmaster at Madrasah Tsanawiyah 
of Bantul Regency, head office of ministry of religious affair of Bantul, head office of religious training of Semarang, and head of religious training centre of Republic Indonesia.

\section{Conclusion}

The character of the learning community at Madrasah Tsanawiyah Bantul Regency of Yogyakarta is conducted through collaborative learning, collegial relationship of teachers, and participation of parents, community, and the government represented by the Office of the Ministry of Religious Affairs of Bantul Regency has not been fit. Collaborative learning is good. However collegial relationship of teachers and participation of parents, community, and government are still need improvement.The implementation of lesson study needs to develop. To realize the learning reform in Madrasah Tsanawiyah of Bantul Regency, the pattern of character learning community development is implemented that is lesson study based on classroom action research, with the stages: (1) consolidating the concept of lesson study; (2) submission of CAR in scientific publication form; (3) planning that includes: problem identification, action identification, title formulation, CAR proposal formulation, lesson study planning; (4) implementation (do); (5) reflection.

The findings in this research are expected to be input for various parties in order to realize the characterized learning community at Madrasah Tsanawiyah of Bantul Regency. For Madrasah Tsanawiyah of Bantul Regency, it is hoped that the head of madrasah, the staff, and teachers will work together to conduct lesson study based on classroom action research. For the Ministry of Religious Affairs Bantul Regency, the development of learning community is expected to facilitate lesson study base on classroom action research as well as Headmaster Working Group, Lesson Teacher Forum, and other development teacher competence at madrasa level. For The Religious Education and Training Office, the lesson study base on 
CAR can be propose as the development of lesson study training and classroom action research training.

For the development of science, the results of this study can be used as input materials in the development of better community character community learning patterns in madrasah through lesson study base on classroom action research. 


\section{REFERENCES}

Amagi, Isao. "Upgrading the Quality of School Education", International Commission on Education for the Twenty-First Century. Paris: UNESCO Publishing, 1996.

Anggara, Rian and Umi Chotimah. "Penerapan Lesson Study Berbasis Musyawarah Guru Mata Pelajaran (MGMP) terhadap Peningkatan Kompetensi Profesional Guru PKn SMP SeKabupaten Ogan Ilir." Jurnal Forum Sosial 5, No. 1, 2015: 107203.

Borg, W.R. and M.D. Gall. Educational Research: an Introduction. London: Longman, 1983.

Danim, Sudarwan. Agenda Pembaharuan Sistem Pendidikan. Yogyakarta: Pustaka Pelajar, 2016.

Delfaleny. "Implementasi Learning Community untuk Meningkatkan Kemampuan Berbicara Siswa Kelas 2 MTsN Model Padang, Tesis, Universitas Malang, 2008.

Kementerian Pendidikan dan Kebudayaan. Peraturan Menteri Pendidikan dan Kebudayaan Nomor 22 Tabun 2016 Tentang Standar Proses Pendidikan Dasar dan Menengah. Jakarta: Kementerian Pendidikan dan Kebudayaan, 2016.

. Kajian dan Pedoman Penguatan Pendidikan Karakter (PPK): Gerakan Penguatan Pendidikan Karakter Tingkat Sekolah Dasar dan Sekolah Menengah Pertama. Jakarta: Kementerian Pendidikan dan Kebudayaan, 2016.

Koesoema, Doni A. Pendidikan Karakter: Strategi Mendidik Anak di Zaman Global. Jakarta: Grasindo, 2010.

Nurkolis. Manajemen Berbasis Sekolah. Jakarta: Grasindo, 2003.

Nuryatno, M. Agus. "Isu-isu Kritis dalam Pendidikan Islam: 
Perspektif Pedagogik Kritis", Nizar Ali and Sumedi (ed.). Antologi Pendidikan Islam. Yogyakarta: Idea Press, 2010.

Peck, M. Scott. Meditations from the Road. New York: Simon and Schuster, 1993.

Pelita. Panduan untuk Peningkatan Proses Belajar dan Mengajar. Jakarta: International Development Center of Japan, 2009.

. Panduan untuk Lesson Study Berbasis MGMP dan Lesson Study Berbasis Sekolah. Jakarta: International Development Center of Japan, 2009.

Pemerintah Republik Indonesia. Amandemen Undang-undang Dasar 1945. Jakarta: Lembaran Negara Republik Indonesia, 2002.

Plomp, T.Ny. Educational and Training System Design. Enschede, The Netherlands: University of Twente, n.y.

Rahayu, P., S. Mulyani, and S.S. Miswadi. "Pengembangan Pembelajaran IPA Terpadu dengan Menggunakan Model Pembelajaran Problem Base Melalui Lesson Study", Jurnal Pendidikan IPA Indonesia 1, No. 1, 2012: 63-70.

Sato, Masaaki. Dialog dan Kolaborasi di Sekolah Menengah Pertama: Praktek Learning Community. Jakarta: JICA, Kementerian Pendidikan dan Kebudayaan, and Kementerian Agama, 2012.

Soleh, Ilman. Dampak Globalisasi bagi Kepribadian Kita. Klaten: Cempaka Putih, 2012.

Sumarni, Sri. "Pengembangan Model Pendidikan Karakter Berbasis Penguatan Modal Sosial bagi Mahasiswa UIN Sunan Kalijaga", Disertasi, Program Studi Ilmu Pendidikan Pascasarjana Universitas Negeri Yogyakarta, 2014.

Sutrisno. Faఇlur Rahman: Kajian terhadap Metode, Epistemologi, dan Sistem Pendidikan. Yogyakarta: Pustaka Pelajar, 2006. 
. Pembaharuan dan Pengembangan Pendidikan Islam: Membentuk Insan Kamil yang Sukses dan Berkualitas. Yogyakarta: Fadilatama, 2011.

- Pendidikan Islam yang Menghidupkan: Studi Kritis terbadap Pemikiran Pendidikan Fazlur Rahman. Yogyakarta: Kota Kembang, 2008.

. Revolusi Pendidikan di Indonesia: Membedah Metode dan Teknike Pendidikan Berbasis Kompetensi. Yogyakarta: Ar-Ruzz, 2005.

- "Mengingat Kembali Jiwa Pendidikan Sebagai Respon terhadap Globalisasi”, Nizar Ali and Sumedi (ed.), Antologi Pendidikan Islam. Yogyakarta: Idea Press, 2010.

Tilaar, H.A.R. Beberapa Agenda Reformasi Pendidikan Nasional dalam Perspektif Abad XXI. Magelang: Indonesia Tera, 1998.

Winarno, Budi. Globalisasi Peluang atau Ancaman bagi Indonesia. Jakarta: Penerbit Erlangga, 2010.

Zainuddin. Reformasi Pendidikan: Kritik Kurikulum dan Manajemen Berbasis Sekolah. Yogyakarta: Pustaka Pelajar, 2008. 
Nurul Kamilati, Sutrisno and Yosaphat Sumardi 